\title{
Effect of Foliar Applications of Urea on Flowering, Fruit set, Yield and Fruit Quality of Washington Navel Orange Trees
}

\section{F. S. El-Sayed, M. M. Abo El-Aenen and Mona M. Helal}

Horticulture Research Institute, Agricultural Research Centre, Cairo, Egypt.

\begin{abstract}
THIS STUDY was carried-out during two successive seasons 2014 and 2015 on 10 -year-old Washington Navel orange trees, cultivated in heavy loamy soil under El-Kalubia governorate conditions. Urea foliar applications at $1 \%$ or $2 \%$ concentrations in one time or twice at both mid of December and January. Morphological and microscopic studies cleared that, both Urea $1 \%$ one-time or twice applications improved the floral initiation and differentiation and reduced blooming process period for Washington Navel orange from 8 to 6 weeks and increased the deformity pollen grains when compared to control. Urea $1 \%$ twice applications significantly improved fruit set and total yield and the most of physical and chemical fruit properties in this study. Moreover, urea $1 \%$ twice applications significantly increased total indols and reduced total phenols in flower buds during blooming stages which positively reflected on fruit setting and yield.
\end{abstract}

Keywords: Urea, Navel orange, Flowering, Fruit quality.

Navel orange yield can be closely related to total flowers in the spring bloom even though most of the flowers do not set fruit that remain until harvest (Moss, 1971). Lord and Eckard (1987) demonstrated that, flower initiation in Navel orange occurred before the end of January, flowering in February to early March, physiological drop in late April to early July and fruit growth from July to November. Climatic stress factors such as cold and drought are natural inducers of flower buds in citrus (Davies \& Albrigo, 1994 and Davenport, 1990).

Foliar sprays of urea have been related to enhance the number of flower buds, flower per inflorescence and yields under California winter conditions (Lovatt et al., 1988a and Ali \& Lovatt, 1992). Whether this is due to short-term ammonium or urea concentration stress due to phytotoxicity (Krogmeier et al., 1989) in the buds or leaves or due to nutritional factors (Lovatt et al., 1988b) was not clear. While, Rabe (1994) mentioned that, timing of application or other factors may be critical. After flower bud differentiation starts, the trees may not be able to translocate sufficient major nutrients $(\mathrm{N}, \mathrm{P}, \mathrm{K})$ for the needs of up to 50,000 to 
100,000 flowers/tree (Erickson and Brannaman,1960). Sagee and Lovatt (1991) found that, foliar urea sprays of Washington Navel orange during the period from November to February (i.e. flower initiation/differentiation, increased yield significantly through an increase in fruit number and size. Moreover, he reported that foliar urea sprays at full bloom and at physiological drop increased fruit number and total yield.

In this study, we present information and data regarding the effect of urea spray treatments on flowering, fruit set and yield of Washington Navel orange trees.

\section{Materials and Methods}

This study was carried-out during two successive seasons (2014 and 2015) on healthy and almost uniform Washington Navel orange trees 10-years-old cultivated in a private farm located in Toukh restrict El-Kalubia governorate, Egypt. The texture of the soil is heavy loamy soil with well drained. Trees grafted on sour orange (C. aurantum L.) rootstock and showed no symptoms of nutritional deficiency, disease, or insect damage.

Commercially available urea $(46 \% \mathrm{~N})$ at $1 \%$ and $2 \% \mathrm{~W} / \mathrm{V}$ was applied as a foliar spray "10 L /tree" on mid- December and mid- January " before flower initiation and differentiation stages".

The following treatments were applied as follows:

T1) Urea at $1 \%$ "mid-December".

T2) Urea $1 \%$ "mid- January".

T3) Urea $1 \%$ "mid-December and mid- January".

T4) Urea $2 \%$ "mid-December".

T5) Urea $2 \%$ "mid- January".

T6) Urea $2 \%$ "mid-December and mid- January".

T7) (control) untreated trees.

\section{Experimental parameters}

Histological study: samples of buds from the terminal part of the spring shoots or the flowers emerged on the shoots were taken and immediately preserved in the FAA solution for killing and fixation. Dehydration with ethanol, clearing with xylene, infiltration and embedding in pure paraffin wax (M.P., 56$58 \mathrm{C})$ were carried-out. Longitudinal section of 10 microns thickness were prepared using a rotary microtome. The prepared slides were stained with saffranin and light green, and examined microscopically for identifying various stages of floral differentiation.

Flowering aspects: in both seasons, four branches as uniform as possible were chosen and tagged around the periphery of each tree at mid-February. Total number of flowers, leafy inflorescence, leafless inflorescence and number of 
setting fruits during flowering and setting stages (mid March to mid May) calculated as formula:

Leafy inflorescence $\%=\underline{\text { Number of leafy inflorescence }} \times 100$

Number of inflorescence

Fruit set $\%=$ Number of developed fruit lets $\times 100$

Persistent number of flowers

Yield and fruit quality: at harvesting time (approximately $1^{\text {st }}$ of January) in both seasons, the number of fruits and yield per tree $(\mathrm{kg})$ were recorded. sample of 10 fruits per each replicate were selected in the $1^{\text {st }}$ week of January to determine the fruit quality as follows: Fruit weight, fruit size, fruit dimensions, peel thickness, juice percentage, total soluble solids (TSS) total acidity (T.AC), TSS/T.AC ratio and vitamin C content according to A.O.A.C. ( 1990 ).

The experiment consists of seven treatments arranged in a randomized complete block design. Three replicates were chosen for each treatment with one tree in each replicate. Least significant differences (L.S.D) at 0.05 (Steel and Torrie, 1984) were used for comparison between the control and the other experimental treatments.

\section{Results and Discussion}

\section{Flowering}

Time of floral initiation and differentiation

Generally, it can be noticed (Table1) that, initiation and differentiation in buds of all treatments and control trees did not show any sign of activity (neutral buds) till January 25. The first sign of floral initiation, the activation of axillary growing cells of swelling buds (stage 1) was first observed on February 2 in T3 followed February 9 in T2 followed February 16 with T4, 5 and 6 then February 23 in $\mathrm{T} 1$ and 7 . At the same time the second stage (broading of axillary apex) and 3 stage sepal primordial and petal initials) was noticed in buds. Stage 4 of floral differentiation (stamen and pistil initials) observed on February 16 in T3 followed by February 23 in T2 then March 1 in T1, 4, 5, 6 and 7. Stage 5 of floral differentiation was first noticed on February 23 in T2 and 3 followed March 1 in T1, 4, 5, 6 and 7. Therefore, the floral initiation and differentiation stages ( 6 and 7) were found on March 1 for T2 and 3 and on March 8 for T1, 4, 5, 6 and 7. While, stage 8 of floral differentiation (microspore tetrads) was first noticed on March 8 in T2 and 3 and on March 15 in T1, 4, 5, 6 and 7. The floral differentiation stages (9 and 10) were found on March 15 in T2, 3 and 5 and on March 22 in T1, 4, 6 and 7. It can be noticed that the ratio of deformity pollen grains was higher in treated urea than control on March 30. These results are in line with obtained by (Badu and Kaul, 1972) they found that, citrus species flower bud differentiation occurred between November and next March. 
TABLE 1. Effect of foliar applications of urea on appearance of differentiate stages of floral differentiation as shown in samples of Washington Navel orange.

\begin{tabular}{|c|c|c|c|c|c|c|c|c|c|c|c|}
\hline $\begin{array}{c}\begin{array}{c}\text { Stages of } \\
\text { floral } \\
\text { differentiation }\end{array} \\
\end{array}$ & $15 / 1$ & $25 / 1$ & $2 / 2$ & $9 / 2$ & $16 / 2$ & $23 / 2$ & $1 / 3$ & $8 / 3$ & $15 / 3$ & $22 / 3$ & $1 / 4$ \\
\hline $1^{\text {st }}$ & & & T3 & $\mathrm{T} 2$ & $\begin{array}{c}\mathrm{T} 4,5, \\
6\end{array}$ & $\mathrm{~T} 1,7$ & & & & & \\
\hline $2^{\text {nd }}$ & & & T3 & $\mathrm{T} 2$ & $\begin{array}{c}\mathrm{T} 4,5, \\
6\end{array}$ & $\mathrm{~T} 1,7$ & & & & & \\
\hline $3^{\text {rd }}$ & & & T3 & $\begin{array}{l}\mathrm{T} 2, \\
5\end{array}$ & T4,6 & $\mathrm{T} 1,7$ & & & & & \\
\hline $4^{\text {th }}$ & & & & & T3 & $\mathrm{T} 2$ & $\begin{array}{c}\mathrm{T} 4,5,6, \\
1,7\end{array}$ & & & & \\
\hline $5^{\text {th }}$ & & & & & & $\mathrm{T} 2,3$ & $\begin{array}{c}\mathrm{T} 1,4,5, \\
6,7\end{array}$ & & & & \\
\hline $6^{\text {th }}$ & & & & & & & $\mathrm{T} 2,3$ & $\begin{array}{l}\mathrm{T} 1,4, \\
5,6,7\end{array}$ & & & \\
\hline $7^{\text {th }}$ & & & & & & & $\mathrm{T} 2,3$ & $\begin{array}{l}\mathrm{T} 1,4, \\
5,6,7\end{array}$ & & & \\
\hline $8^{\text {th }}$ & & & & & & & & $\mathrm{T} 2,3$ & $\begin{array}{l}\mathrm{T} 1,4, \\
5,6,7\end{array}$ & & \\
\hline $9^{\text {th }}$ & & & & & & & & & $\begin{array}{c}\mathrm{T} 2,3, \\
5\end{array}$ & $\begin{array}{c}\mathrm{T} 1,4, \\
6,7\end{array}$ & \\
\hline $10^{\text {th }}$ & & & & & & & & & $\begin{array}{c}\mathrm{T} 2,3, \\
5\end{array}$ & $\begin{array}{c}\mathrm{T} 1,4, \\
6,7\end{array}$ & \\
\hline
\end{tabular}

Floral initiation and differentiation

The histological studies showed that, floral differentiation in Washington Navel orange trees was closely related with bud burst activity, therefore, it was necessary to determine the process of floral bud burst, prior to floral initiation and differentiation studies. The following morphological stages of floral bud burst was noticed:

Dormant bud: This bud is still morphological inactive.

Swelling bud: This stage involves any bud which begin to show enlargement in its size.

Bud burst: The progressive development of this bud gave some leaf primordial with floral initials.

Elevated flower: The axillary flower primordial appears as a result of the elongation of their pedicels. The flower primordial is characterized the green colour as a result of the enclosed calyx.

Splitted sepals: The white colour begins to appear through the edges of the calyxlobes which splitted as a result of increasing internal pressure caused by the developmental inner organs.

Round stage: The white colour covers the upper half of the flowers which increased in growth and turgidity.

Ballon stage: in this stage, more elongation of the flowers was noticed and the white colour of the enclosed corolla proceeds.

Advanced ballon stage: The endlosed which corolla was more elongation and turgidity at this stage.

Egypt. J. Hort. Vol. 43, No.2 (2016) 
Fully opened flowers: The opening phase of the flowers is attains as a result of the Petal expanstion.

The microscopic studies cleared that the apical merstem of the bursting bud had the dome-like shape with no activation points (Fig.1, 2). Therefore, ten successive stages of floral differentiation are obtained:

The axillary growing points of bursting bud started their activation and having the dome-Like shape (Fig.1, 2 ).

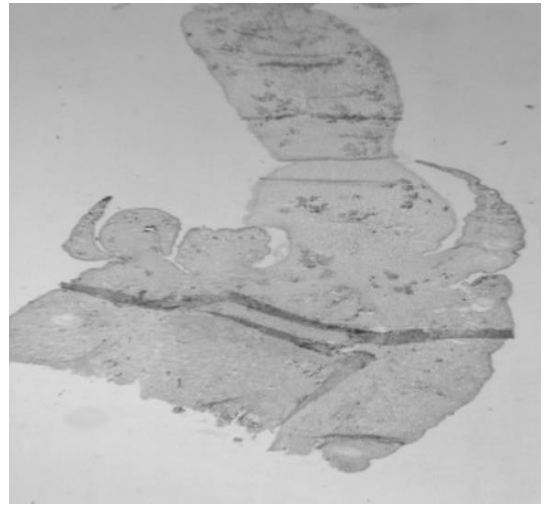

Fig. 1. Stage (1) General feature (x40).

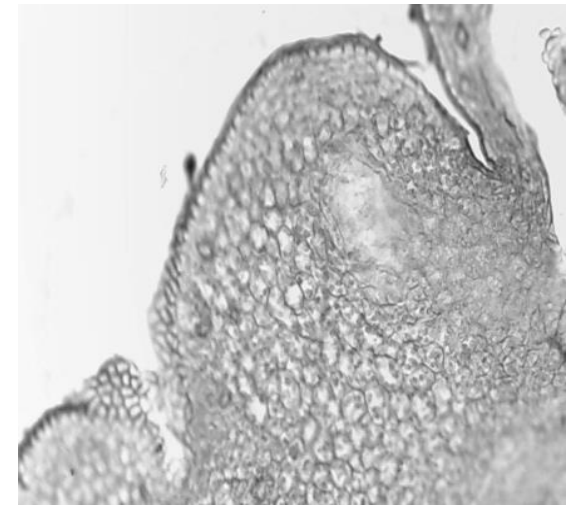

Fig. 2. Stage (1) Initiation of the generative activity of the lateral apex (x4o).

A broading of axilary growing $p$

A broading of axilary growing point apex could be observed in this stage (Fig. 3).

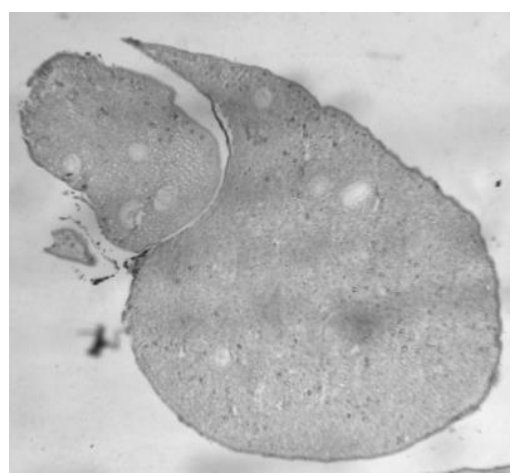

Fig. 3. Stage (2) Flattening of the floral apex (x40).

In this stage, sepal primordia was developed and petal initials start to differentiate within sepal primordia (Fig. 4,5). 


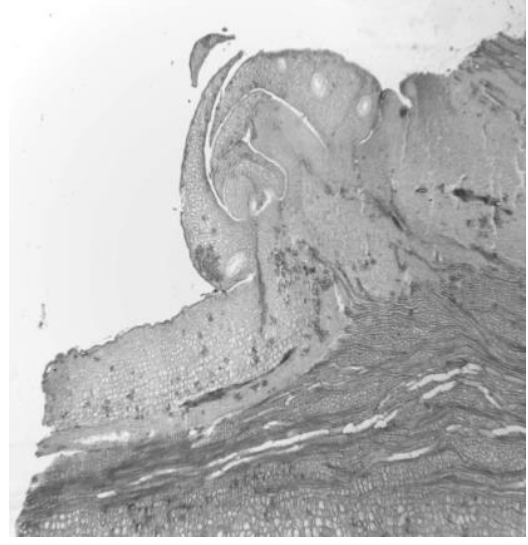

Fig. 4. Stage (3) Appearance of petal primordial $(\mathbf{x 4 0})$

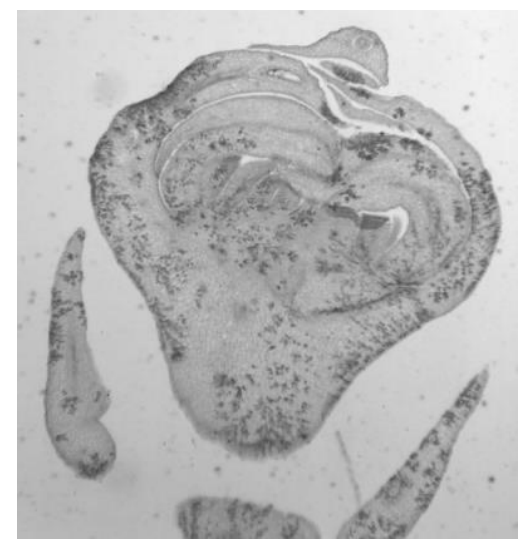

Fig. 5. Stage (3)Appearance of petal primordial $(\mathbf{x} 40)$

It can be noticed the appearance of stamen and pistil initials within the develop in sepal and petal primordial in stage 4 (Fig. 6,7).

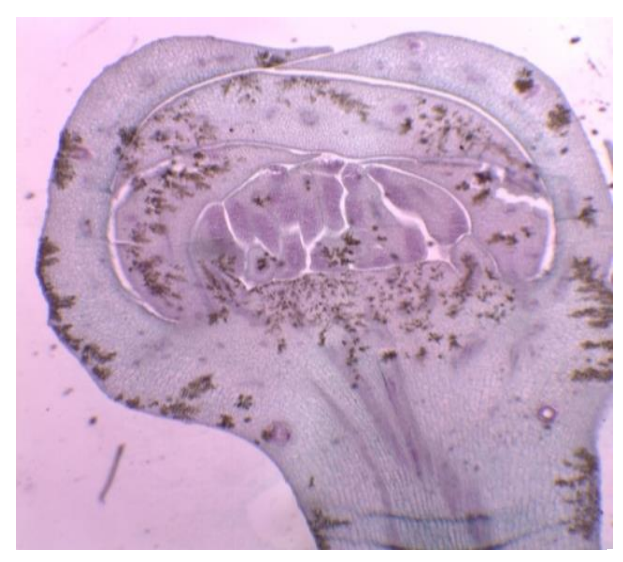

Fig. 6. Stage (4) General feature (x40).

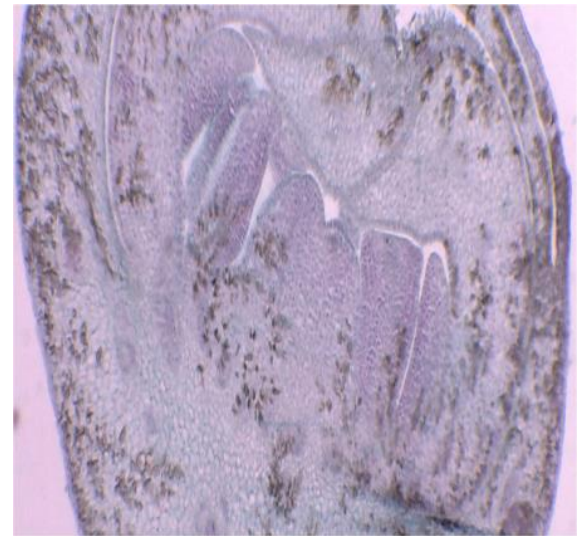

Fig. 7. Stage (4) Appearance of stamin and pistil primordial $(\mathbf{x} 400)$.

This stage is characterized by This stage is characterized by

- The differentiation of stamen primordia into filaments and anthers (Fig. 8 ).

- The pistil primordial elongated through upward growth, the style and stigma were slightly distinct and also the ovary cavities could be seen ( Fig. 8 ). 


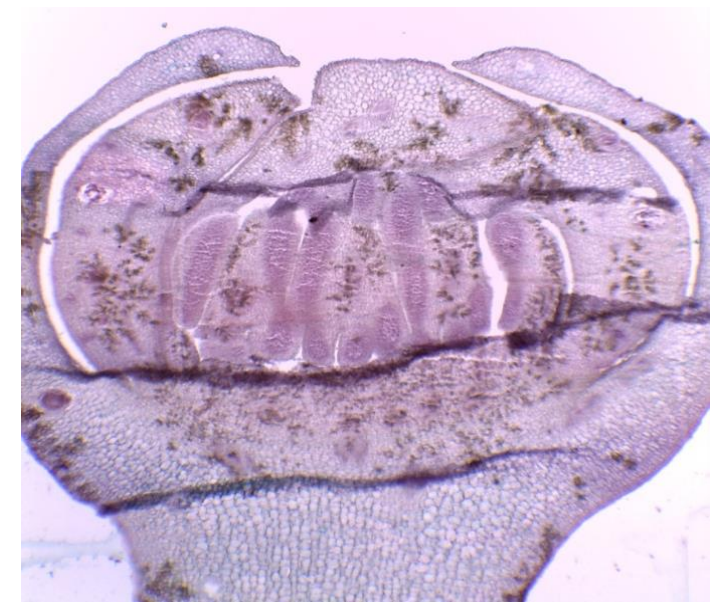

Fig. 8. Stage (5) Ovary cavity (x400).

Appearance of ovule initials occurs in this stage (Fig. 9). The anther locules became some what obvious as the epidermal and the archesporial cells are clearly distinguished (Fig. 9).

In this stage, the ovarian cavities showed further enlargement and bending of the developing ovules could be observed (Fig.10), also, the pollen mother cells are closely packed within anther locules.

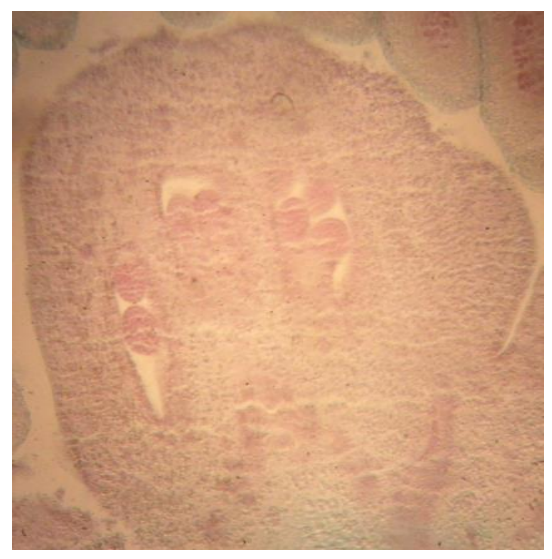

Fig. 9. Stage (6) initials and pending of ovule primordial (x 40).

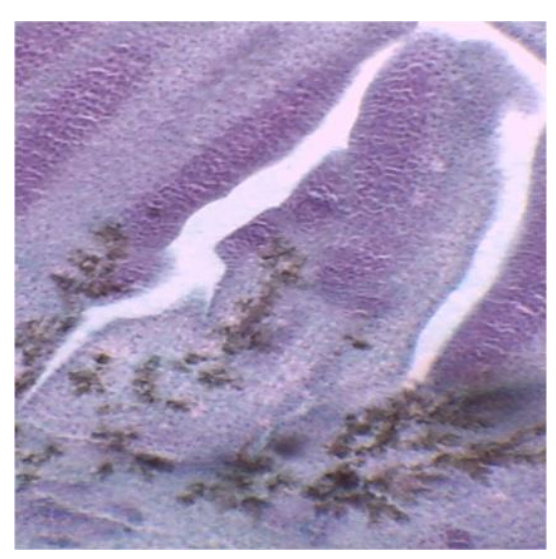

Fig. 10. Stage (7) Elongation of ovule primordial

Egypt. J. Hort. Vol. 43, No.2 (2016) 
At this stage, each of pollen mother cells was divided into four microspore tetrads (Fig. 11).

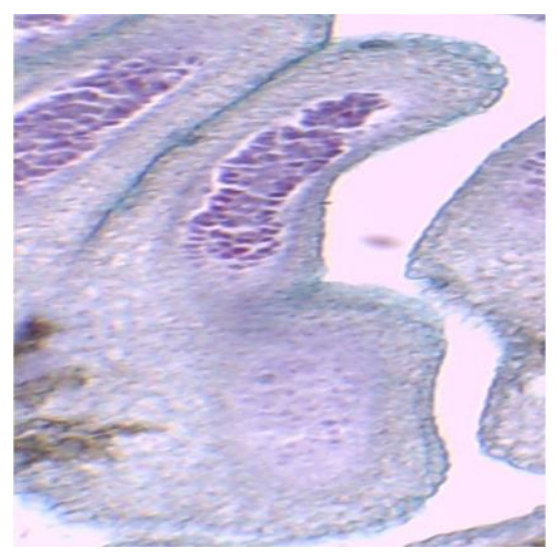

Fig. 11. Stage (8) Differentiation of microspore tetrads.

Mature pollen grains are showed (Fig. 12) and the integuments of the developing ovules are formed of this stage.
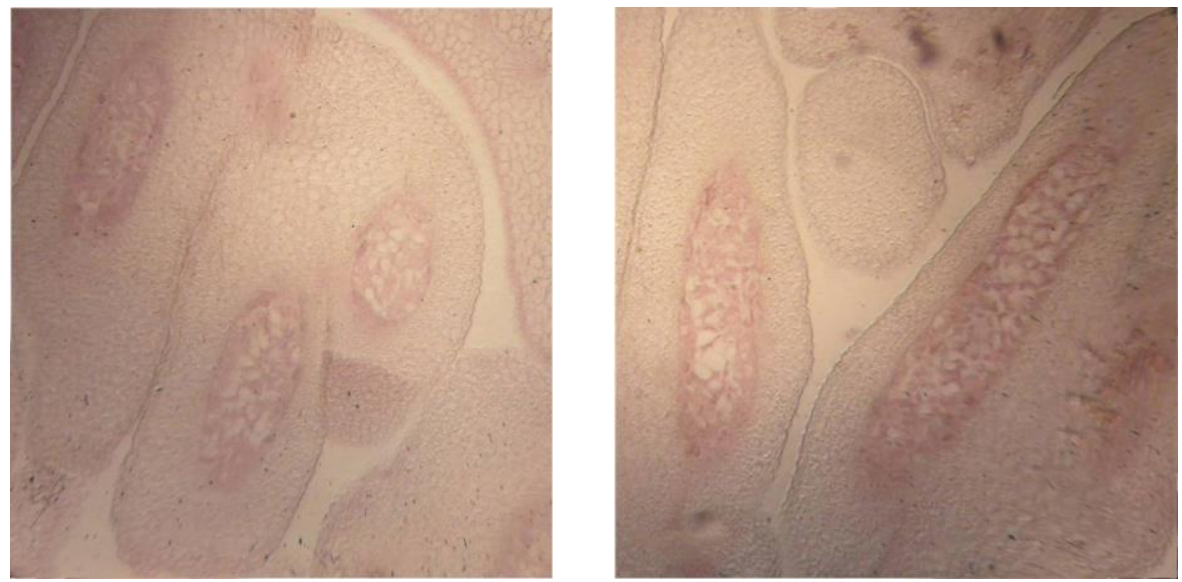

Fig. 12. Stage (9) Pollen grains in control and treated tree (x 40).

This stage is characterized by the appearance of embryo sacs with the 10-This stage is characterized by the appearance of embryo sacs with the developing ovules (Fig. 13). These results are similar to those of (Mostafa, 1985).

Egypt. J. Hort. Vol. 43, No.2 (2016) 


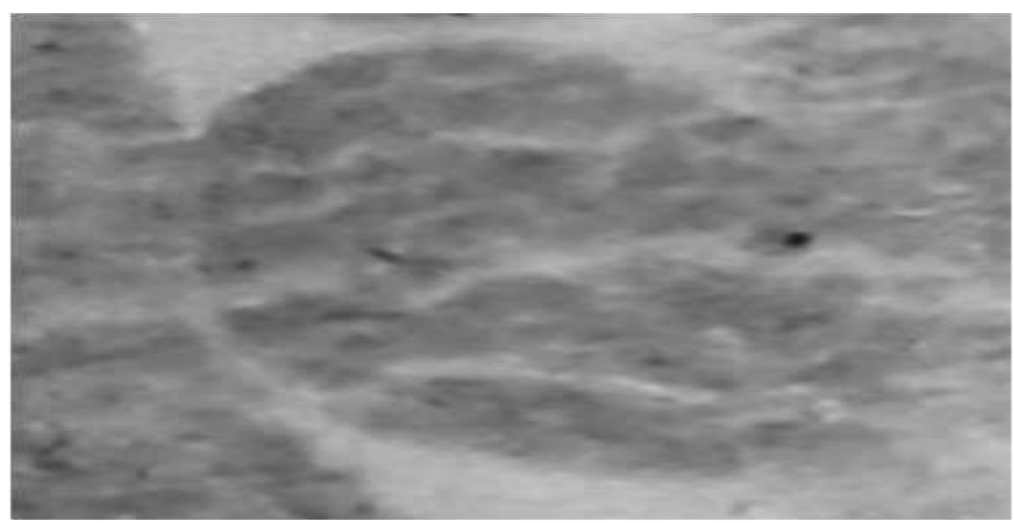

Fig. 13. Stage (10) Completely differentiated anatropous ovules (x40).

\section{Flowering process}

Generally, blooming of Navel orange trees started from late February to early March. Treated trees of urea started to bloom later and ended earlier than untreated trees (Table 2). Duration of blooming was about 60 day from the later and around 40-50 day for the former. These results are in line with those obtained by (Lord and Eckard 1987) they demonstrated that flower initiation in Navel orange [Citrus sinesis L. Osb.] occurred before the end of January, flowering in February to early March.

TABLE 2. Effect of foliar applications of urea on flowering process.

\begin{tabular}{|l|c|c|c|c|c|c|c|c|}
\hline \multirow{2}{*}{ Treatments } & \multicolumn{7}{|c|}{ Flowering process } \\
\cline { 2 - 9 } & \multicolumn{2}{|c|}{ Balloon stage } & \multicolumn{2}{c|}{ Flowering } & \multicolumn{2}{c|}{ Full bloom } & \multicolumn{2}{c|}{ Petal full stage } \\
\cline { 2 - 9 } & S1 & S2 & S1 & S2 & S1 & S2 & S1 & S2 \\
\hline T1 Urea 1\% & $20 / 2$ & $25 / 2$ & $25 / 3$ & $29 / 3$ & $3 / 4$ & $7 / 4$ & $11 / 4$ & $16 / 4$ \\
in Mid December . & & & & & & & & \\
\hline T2 Urea 1\% \\
in Med January .
\end{tabular}

\section{Blooming and setting}

Data in Table 3 cleared that, total number of flowers significantly increased with urea treatments compared with control. The maximum flower number was (136.25 and 120.50) at T5 followed by T6 (99.00 and 101.70) then T4 (98.75 and 102.40) followed by T2 (85 and 87) while, the lowest significant flower number was obtained with T1(80.75 and 83.50) and T3 (81.67 and 84.30) for both 
seasons, respectively. These results are in agreement with (Lovatt et al., 1988a, 1988b) they demonstrated that, foliar application urea raised the tree ammonia status and increased both the number of inflorescences per tree and flowers per inflorescence.

Concerning leafy inflorescence percentage(LY)\%, the results in Table 3 showed that, the greatest significant Ly \% was recorded with T5 (74.17 and 76.25 ) followed by T3 (65.14 and 70.20) then T6 (63.29 and 66.40), while, the lowest significant Ly \% was obtained with T4(57.95 and 60.71) followed by $\mathrm{T} 1(57.38$ and 61.30) then $\mathrm{T} 2(56.86$ and 62.50), respectively for both seasons when compared with control.

These results are harmony with (Sagee and Lovatt, 1991) they reported that, the metabolism of ammonia to arginine and arginine to polyamines were linked in Navel orange flowers and developing fruit. Moreover, (Lovatt et al., 1992) found that developing flowers and post petal fruit borne on leafy inflorescence were characterized by significantly higher polyamine concentrations, faster growth rates and a greater percent fruit set than those born on leafless inflorescences.

Fruit set percentage: First and second seasons results as shown in Table 3 indicated that, fruit set $\%$ significantly increased in both seasons with treatments of urea when compared with control, the maximum significant values were obtained with T3 ( 3.95 and 3.81 ) followed by T6 (3.75 and 3.77) then T4( 3.64 and 3.75) followed by $\mathrm{T} 2(3.48$ and 3.50) and finally $\mathrm{T} 5(3.43$ and 3.47) followed by T1(3.58 and 3.20), respectively for both seasons, while the lowest significant was obtained with control. These results was confirmed by (El-Otmani et al., 1998a, 1998b, 2000a, 2000b), Ali and Lovatt (1992) and Lovatt (1999) they demonstrated that, urea application to Navel orange trees during fall/winter months increased yield as a result of increased flower initiation and fruit set.

TABLE 3. Effect of foliar applications of urea on blooming and fruit-set.

\begin{tabular}{|l|c|c|c|c|c|c|}
\hline \multirow{2}{*}{ Treatments } & \multicolumn{2}{|c|}{$\begin{array}{c}\text { Total number of } \\
\text { flowers }\end{array}$} & \multicolumn{2}{c|}{ Leafy inflorescences } & \multicolumn{2}{c|}{ Fruit -set } \\
\cline { 2 - 7 } & S1 & S2 & S1 & S2 & S1 & S2 \\
\hline $\begin{array}{l}\text { T1 Urea 1\% } \\
\text { in Mid December. }\end{array}$ & 80.75 & 83.5 & 57.38 & 61.30 & 3.58 & 3.20 \\
\hline $\begin{array}{l}\text { T2 Urea 1\% } \\
\text { In Med January. }\end{array}$ & 85.00 & 87.00 & 56.86 & 62.50 & 3.48 & 3.50 \\
\hline $\begin{array}{l}\text { T3 Urea 1\% in } \\
\text { Mid Dec .and Jan. }\end{array}$ & 81.67 & 84.30 & 65.14 & 70.20 & 3.95 & 3.81 \\
\hline $\begin{array}{l}\text { T4 Urea 2\% } \\
\text { in Mid December }\end{array}$ & 98.75 & 102.40 & 57.95 & 60.71 & 3.64 & 3.75 \\
\hline $\begin{array}{l}\text { T5 Urea 2\% } \\
\text { in Med January. }\end{array}$ & 136.25 & 120.50 & 74.17 & 76.25 & 3.43 & 3.47 \\
\hline $\begin{array}{l}\text { T6 Urea 2\% in } \\
\text { Mid Dec .and Jan. }\end{array}$ & 99.00 & 101.70 & 63.29 & 66.40 & 3.75 & 3.77 \\
\hline $\begin{array}{l}\text { T7 Untreated } \\
\text { control " }\end{array}$ & 79.25 & 82.50 & 53.73 & 55.60 & 1.47 & 2.30 \\
\hline L.S.D 5\% & 4.03 & 3.72 & 6.88 & 6.31 & 0.13 & 0.17 \\
\hline
\end{tabular}

Egypt. J. Hort. Vol. 43, No.2 (2016) 
Yield

Data in Table 4 indicated that, urea applications increased yield as a number of fruits per tree and kg per tree compared with control. The maximum fruit yield were $(350$ and 330$)$ fruit per tree and $(103.25,90.75) \mathrm{kg}$ per tree with T3 followed by T2 $(305$ and 320$)$ fruit per tree and $(82.96,89.60) \mathrm{kg}$ per tree then $\mathrm{T} 1$ (280 and 300) fruit per tree and $(74.20,80.40) \mathrm{kg}$ per tree followed by T5(260 and 280$)$ fruits per tree and $(72.28,78.40) \mathrm{kg}$ per tree and finally T6 (225 and 230) fruits per tree and $(55.35,57.96) \mathrm{kg}$ per tree followed by $\mathrm{T} 4$ (210 and 218) fruits per tree and $(49.98,54.50) \mathrm{kg}$ per tree for both seasons, respectively.

These results are in agreement with (Ali and Lovatt, 1994) who found that, successfully increased fruit set and yield of the Washington Navel orange with a single foliar winter pre-bloom application of low biuret urea. Also, (Ali and Lovatt, 1992) they reported that, January or February foliar applied urea resulted in net cumulative increased in yield over the control of 20.6 and 16.4 ton/ha. Moreover, the same results were found by (El-Otmani et al., 1998a, 1998b, 2000a, 2000b), Ali and Lovatt (1992) and Lovatt (1999) they demonstrated that, urea application to Navel orange trees during fall/winter months increased yield as a result of increased flower initiation and fruit set.

TABLE 4. Effect of foliar applications of urea on fruit yield.

\begin{tabular}{|l|c|c|c|c|}
\hline \multirow{2}{*}{ Treatments } & \multicolumn{2}{|c|}{ Yield number of fruits/tree } & \multicolumn{2}{c|}{ Kg / tree } \\
\cline { 2 - 5 } & S1 & S2 & S1 & S2 \\
\hline $\begin{array}{l}\text { T1 Urea 1\% } \\
\text { in Mid December }\end{array}$ & 280 & 300 & 74.20 & 80.40 \\
\hline $\begin{array}{l}\text { T2 Urea 1\% } \\
\text { in Med January. }\end{array}$ & 305 & 320 & 82.96 & 89.60 \\
\hline $\begin{array}{l}\text { T3 Urea 1\% in } \\
\text { Mid Dec .and Jan. }\end{array}$ & 350 & 330 & 103.25 & 90.75 \\
\hline $\begin{array}{l}\text { T4 Urea 2\% } \\
\text { in Mid December }\end{array}$ & 210 & 218 & 49.98 & 54.50 \\
\hline $\begin{array}{l}\text { T5 Urea 2\% } \\
\text { in Med January. }\end{array}$ & 260 & 280 & 72.28 & 78.40 \\
\hline $\begin{array}{l}\text { T6 Urea 2\% in } \\
\text { Mid Dec .and Jan. }\end{array}$ & 225 & 230 & 55.35 & 57.96 \\
\hline $\begin{array}{l}\text { T7 Untreated } \\
\text { Control"'" }\end{array}$ & 175 & 185 & 41.30 & 44.40 \\
\hline L.S.D 5\% & 24.82 & 21.30 & 5.95 & 5.22 \\
\hline
\end{tabular}

\section{Fruit quality}

Physical fruit properties

Fruit weight: The results were given in Table 5 showed that, urea application increased fruit weight compared to the control, the highest significant fruit weight was (295 and $280 \mathrm{~g}$ ) with T3 followed by T5 (278 and $280 \mathrm{~g})$ then T2 (272 and $275 \mathrm{~g}$ ) followed by T1 (265 and 268) while, the lowest significant 
values were (238 and $250 \mathrm{~g}$ ) with T4 followed by T6 (246 and $252 \mathrm{~g}$ ) for both seasons, respectively.

Fruit size: First and second seasons results as shown in (Table 5) indicated that, fruit size was significantly increased with treatment of urea compared with farm control, the greatest significant values $(310$ and $283 \mathrm{ml})$ recorded with $\mathrm{T} 3$ followed by T5 $(295$ and $285 \mathrm{ml})$ then T2 $(282,284 \mathrm{ml})$ followed by T1 (267, $270 \mathrm{ml})$ and finally T6 $(260,255 \mathrm{ml})$ followed by T4 $(256,258 \mathrm{ml})$ for both seasons, respectively.

Fruit shape index: Data in Table 5 indicated that, Fruit shape was not affected by treatment of urea for both seasons.

Peel thickness: Data presented in Table 5 showed that, urea applied increased peel sickness compared with control, the highest values with T6 $(0.50,0.51 \mathrm{~cm})$ followed by T4 $(0.48,0.49 \mathrm{~cm})$ then $\mathrm{T} 2(0.49,0.48 \mathrm{~cm})$ and the finally T5 $(0.47$, $0.48 \mathrm{~cm}$ ) but the other treatments gave the intermediate values for both season, respectively.

TABLE 5. Effect of foliar applications of urea on physical fruit properties.

\begin{tabular}{|l|c|c|c|c|c|c|c|c|c|c|}
\hline \multirow{2}{*}{ Treatments } & \multicolumn{1}{c|}{$\begin{array}{c}\text { Fruit } \\
\text { weight } \\
\text { g }\end{array}$} & \multicolumn{2}{|c|}{$\begin{array}{c}\text { Fruit size } \\
\text { MI }\end{array}$} & \multicolumn{2}{c|}{$\begin{array}{c}\text { Truit shape } \\
\text { Index }\end{array}$} & $\begin{array}{c}\text { Peel sickness } \\
\text { cm }\end{array}$ & \multicolumn{2}{c|}{$\begin{array}{c}\text { Juice } \\
\text { \% }\end{array}$} \\
\cline { 2 - 11 } & S1 & S2 & S1 & S2 & S1 & S2 & S1 & S2 & S1 & S2 \\
\hline $\begin{array}{l}\text { T1 Urea 1\% } \\
\text { in Mid December }\end{array}$ & 265 & 268 & 267 & 270 & 1.09 & 1.11 & 0.44 & 0.46 & 38.9 & 40.4 \\
\hline $\begin{array}{l}\text { T2 Urea 1\% } \\
\text { in Med January. }\end{array}$ & 272 & 275 & 282 & 284 & 1.20 & 1.15 & 0.49 & 0.48 & 37.9 & 39.6 \\
\hline $\begin{array}{l}\text { T3 Urea 1\% in } \\
\text { Mid Dec .and Jan. }\end{array}$ & 295 & 280 & 310 & 283 & 1.05 & 1.07 & 0.47 & 0.47 & 37.0 & 39.5 \\
\hline $\begin{array}{l}\text { T4 Urea 2\% } \\
\text { in Mid December }\end{array}$ & 238 & 250 & 256 & 258 & 1.08 & 1.09 & 0.48 & 0.49 & 37.4 & 37.5 \\
\hline $\begin{array}{l}\text { T5 Urea 2\% } \\
\text { in Med January. }\end{array}$ & 278 & 280 & 295 & 285 & 1.0 & 1.05 & 0.47 & 0.48 & 39.2 & 38.7 \\
\hline $\begin{array}{l}\text { T6 Urea 2\% in } \\
\text { Mid Dec .and Jan. }\end{array}$ & 246 & 252 & 260 & 255 & 1.03 & 1.02 & 0.50 & 0.51 & 44.3 & 41.8 \\
\hline $\begin{array}{l}\text { T7 Untreated } \\
\text { Control"" }\end{array}$ & 236 & 240 & 236 & 242 & 1.19 & 1.16 & 0.43 & 0.46 & 47.0 & 44.5 \\
\hline L.S.D 5\% & 15.6 & 12.7 & 11.8 & 9.5 & N.S & N.S & N.S & N.S & 2.01 & 1.85 \\
\hline
\end{tabular}

Juice percentage: Results showed that, urea application decreased juice \% compared with control, the lower values $(37.4,37.5)$ with T4 followed by T3 (37, 39.5 ) but the other treatments gave the intermediate values for the first and second seasons. Generally, it could be concluded that, foliar application of urea increased fruit weight, fruit size, fruit shape index and peel sickness and reduced juice \% compared with control. These results are in line with (Lovatt, 1999) they reported that, urea applied of Washington Navel orange trees at a final concentration of $1.3 \% \mathrm{~N}$ providing $0.16 \mathrm{~kg} \mathrm{~N} /$ tree significantly increased both

Egypt. J. Hort. Vol. 43, No.2 (2016) 
total weight and number of fruit per tree. Moreover, the number of commercially valuable large-size fruit also increased significantly with yield increases. Also, the same results were found by (El-Otmani et al., 2000) yield increase was due to an increase in fruit number and size.

\section{Chemical fruit properties}

Total soluble solids content (TSS): Data in Table 6 showed that, urea applications increased TSS \% compared with control, the higher significant values were $(13,12.8 \%)$ with $\mathrm{T} 1$ followed by $\mathrm{T} 3(13,12.6 \%)$ then $\mathrm{T} 4(12.8$, $12.4 \%)$ and finally $\mathrm{T} 2(12.5,12.2 \%)$ while, the other treatments gave the intermediate values for both seasons.

Total acidity: First and second seasons as shown in Table 6 indicated that, total acidity $\%$ of fruits was decreased significantly by urea applications compared with control. The greatest values recorded with control $(0.70$ and $0.71 \%)$ while, the lowest values were $(0.59$ and $0.60 \%)$ with $\mathrm{T} 1$ and T3 but the other treatments gave the intermediate values for both seasons, respectively.

TSS/T.AC ratio: The results showed that, TSS/T.AC ratio was significantly higher by treatment of urea compared to the control, the highest significant values was obtained with $\mathrm{T} 1(22.03,21.33)$ followed by T3 $(22.03,21.00)$ then T4 (20, 18.24). The lowest significant values recorded with T6 $(17.39,16.59)$ while, the other treatments gave the intermediate values for the first and second seasons, respectively.

TABLE 6. Effect of foliar applications of urea on chemical fruit properties

\begin{tabular}{|l|c|c|c|c|c|c|c|c|}
\hline \multirow{2}{*}{\multicolumn{1}{|c|}{ Treatments }} & \multicolumn{2}{|c|}{ T.S.S \% } & \multicolumn{2}{c|}{ T.AC \% } & \multicolumn{2}{c|}{ T.S.S /T.AC } & \multicolumn{2}{c|}{$\begin{array}{c}\text { Vit .C } \\
\text { Ratio }\end{array}$} \\
\cline { 2 - 9 } & S1 & S2 & S1 & S2 & S1 & S2 & S1 & S2 \\
\hline $\begin{array}{l}\text { T1 Urea 1\% } \\
\text { in Mid December }\end{array}$ & 13.0 & 12.8 & 0.59 & 0.60 & 22.03 & 21.33 & 32.53 & 34.20 \\
\hline $\begin{array}{l}\text { T2 Urea 1\% } \\
\text { in Med January. }\end{array}$ & 12.5 & 12.2 & 0.65 & 0.66 & 19.23 & 18.48 & 33.06 & 34.20 \\
\hline $\begin{array}{l}\text { T3 Urea 1\% in } \\
\text { Mid Dec .and Jan. }\end{array}$ & 13.0 & 12.6 & 0.59 & 0.60 & 22.03 & 21.00 & 34.08 & 36.30 \\
\hline $\begin{array}{l}\text { T4 Urea 2\% } \\
\text { in Mid December }\end{array}$ & 12.8 & 12.4 & 0.65 & 0.68 & 20.00 & 18.24 & 30.41 & 31.20 \\
\hline $\begin{array}{l}\text { T5 Urea 2\% } \\
\text { in Med January. }\end{array}$ & 12.0 & 11.8 & 0.61 & 0.63 & 19.67 & 18.73 & 31.20 & 32.20 \\
\hline $\begin{array}{l}\text { T6 Urea 2\% in } \\
\text { Mid Dec .and Jan. }\end{array}$ & 12.0 & 11.6 & 0.69 & 0.70 & 17.39 & 16.57 & 30.14 & 31.80 \\
\hline $\begin{array}{l}\text { T7 Untreated } \\
\text { Control " }\end{array}$ & 11.7 & 11.8 & 0.70 & 0.71 & 16.71 & 16.62 & 30.11 & 30.60 \\
\hline L.S.D 5\% & 0.62 & 0.53 & 0.019 & 0.020 & 2.1 & 1.80 & 2.04 & 2.01 \\
\hline
\end{tabular}

Vit. C. content: The maximum Vit. C. content was resulted with T3 (34.08, 36.30) followed by $\mathrm{T} 2(33.06,34.20)$ then $\mathrm{T} 1(32.53,34.20)$, the farm control had the middle Vit. C. content, but the other treatments gave the intermediate values for both seasons, respectively. These results are in harmony with (Albrigo, 1999) they reported that, winter urea spray significantly increased yield and 
orange juice soluble solids. Moreover, (Lovatt, 1999) indicated that, foliar application of urea resulted in increased yield and/ or fruit size and ratio of total soluble solids to acidity.

\section{Indols and phenols content}

Total indols content: Data tabulated in Table 7 showed that, urea application increased total indols content of Washington Navel orange leaves compared with control. The higher significant values recorded by $\mathrm{T} 2(0.63,0.65)$ followed by T3 $(0.62,0.65)$ during 1 st February and $(0.59,0.62)$ with T6 during 1 st March and $(0.62,0.65)$ with T4 during 1st April. While, the lower significant values were $(0.38,0.41)$ with T1 during 1 st February and $(0.30,0.35)$ with T5 during 1st March and $(0.50,0.53)$ with T6 during 1st April. But the other treatments gave the intermediate values for both seasons, respectively.

TABLE 7. Effect of foliar applications of urea on total indols content of flower buds.

\begin{tabular}{|c|c|c|c|c|c|c|}
\hline \multirow{3}{*}{ Treatments } & \multicolumn{6}{|c|}{ Total indols of flower buds (mg /100 g) } \\
\hline & \multicolumn{2}{|c|}{$1^{\text {st }}$ February } & \multicolumn{2}{|c|}{ 1 $^{\text {st }}$ March } & \multicolumn{2}{|c|}{$1^{\text {st }}$ April } \\
\hline & S1 & $\mathbf{S 2}$ & S1 & S2 & S1 & S2 \\
\hline $\begin{array}{l}\text { T1 Urea } 1 \% \\
\text { in Mid December }\end{array}$ & 0.38 & 0.41 & 0.55 & 0.57 & 0.59 & 0.61 \\
\hline $\begin{array}{l}\text { T2 Urea 1\% } \\
\text { In Med January. }\end{array}$ & 0.63 & 0.65 & 0.50 & 0.53 & 0.57 & 0.59 \\
\hline $\begin{array}{l}\text { T3 Urea 1\% in } \\
\text { Mid Dec .and Jan. }\end{array}$ & 0.62 & 0.65 & 0.52 & 0.55 & 0.61 & 0.64 \\
\hline $\begin{array}{l}\text { T4 Urea } 2 \% \\
\text { in Mid December. }\end{array}$ & 0.55 & 0.57 & 0.48 & 0.50 & 0.62 & 0.65 \\
\hline $\begin{array}{l}\text { T5 Urea 2\% } \\
\text { in Med January. }\end{array}$ & 0.56 & 0.59 & 0.30 & 0.35 & 0.62 & 0.64 \\
\hline $\begin{array}{l}\text { T6 Urea 2\% in } \\
\text { Mid Dec .and Jan. }\end{array}$ & 0.52 & 0.55 & 0.59 & 0.62 & 0.50 & 0.53 \\
\hline $\begin{array}{l}\text { T7 Untreated } \\
\text { Control " }\end{array}$ & 0.53 & 0.54 & 0.54 & 0.55 & 0.53 & 0.57 \\
\hline L.S.D $5 \%$ & 0.05 & 0.06 & 0.02 & 0.03 & 0.04 & 0.04 \\
\hline
\end{tabular}

Total phenols content: total phenols content significantly decreased with urea treatments, compared with control (Table 8$)$. The higher values were $(0.14,0.17)$ and $(0.23,0.20)$ and $(0.25,0.22)$ under control during February, March and April, respectively for both season.

While, the lower values recorded by T3 $(0.12,0.12)$ during February and $(0.12,0.13)$ with T2, 3 during March and $(0.12,0.15)$ during April. But the other treatments gave the intermediate values for both season, respectively. These results are in line with (Norbaek et al., 2003) they reported that, the accumulation of phenolic compounds in plant tissues is often negatively affected by high $\mathrm{N}$ nutrition. This was described for barley, for apricot fruits ( Radi et al., 2003) and recently, for tobacco.

Egypt. J. Hort. Vol. 43, No.2 (2016) 
(Matros et al., 2006). It was also shown for red pine (Blodgett et al., 2003). The same results obtained by (Witzell and shevtsova 2004) they found that, Nfertilisation reduced the concentration of individual phenols in leaves of vaccinium myrtillus.

TABLE 8. Effect of foliar applications of urea on total phenols content of flower buds.

\begin{tabular}{|c|c|c|c|c|c|c|}
\hline \multirow{3}{*}{ Treatments } & \multicolumn{6}{|c|}{ Total phenols of flower buds ( \% ) } \\
\hline & \multicolumn{2}{|c|}{$1^{\text {st }}$ February } & \multicolumn{2}{|c|}{ 1 $^{\text {st }}$ March } & \multicolumn{2}{|c|}{$1^{\text {st }}$ April } \\
\hline & S1 & $\mathbf{S 2}$ & S1 & $\mathbf{S 2}$ & S1 & $\mathbf{S 2}$ \\
\hline $\begin{array}{l}\text { T1 Urea } 1 \% \\
\text { in Mid December. }\end{array}$ & 0.11 & 0.13 & 0.12 & 0.14 & 0.24 & 0.23 \\
\hline $\begin{array}{l}\text { T2 Urea 1\% } \\
\text { in Med January. }\end{array}$ & 0.12 & 0.13 & 0.12 & 0.13 & 0.12 & 0.15 \\
\hline $\begin{array}{l}\text { T3 Urea } 1 \% \text { in } \\
\text { Mid Dec .and Jan. }\end{array}$ & 0.12 & 0.12 & 0.12 & 0.13 & 0.24 & 0.22 \\
\hline $\begin{array}{l}\text { T4 Urea 2\% } \\
\text { in Mid December. }\end{array}$ & 0.12 & 0.14 & 0.22 & 0.18 & 0.23 & 0.24 \\
\hline $\begin{array}{l}\text { T5 Urea 2\% } \\
\text { in Med January. }\end{array}$ & 0.11 & 0.14 & 0.14 & 0.15 & 0.23 & 0.25 \\
\hline $\begin{array}{l}\text { T6 Urea } 2 \% \text { in } \\
\text { Mid Dec .and Jan. }\end{array}$ & 0.11 & 0.13 & 0.21 & 0.19 & 0.23 & 0.25 \\
\hline $\begin{array}{l}\text { T7 Untreated } \\
\text { Control " }\end{array}$ & 0.14 & 0.17 & 0.23 & 0.20 & 0.25 & 0.22 \\
\hline L.S.D $5 \%$ & 0.02 & 0.02 & 0.03 & 0.3 & 0.02 & 0.03 \\
\hline
\end{tabular}

\section{References}

Albrigo, L.G. (1999) Effects of foliar applications of urea or nutriphite on flowering and yields of Valencia orange trees. Proc. Fla. State. Hort. Soc., 112, 1-4.

Ali, A.G. and Lovatt, C.J. (1992) Winter application of low biuret urea to the foliage of Washington Navel orange increased yield. J. Amer. Soc. Hort. Sci., 119, 1144-1150.

Ali, A.G. and Lovatt, C.J. (1994) Winter application of foliar urea. Citrograph., 78, 7-9.

A.O.A.C. (1990) Association of Official Agriculture Chemist. "Official Methods of Analysis" $9^{\text {th }}$ ed., 823 p. Ef., Benjamin Firmin Station , Washington..

Badu, H. and Kaul G.L. (1972) Studies on time of fruit bud differentiation in sweet orange (Citrus sinensis Osbeck) varieties under Tarai. (Upland) conditions of U.P. Punjab Hort. J., 12 (2/3), 93-96, (Hort. Abst., 43: 9101).

Blodgett, J. T., Bonello, P. and Herms, D. A. (2003) Fertilization decreases resistance of red pin to the Sphaeropsis Canker pathogen. Phytopathology.93, ( Suppl 6 ) S 9.

Davenport, T.L. (1990) Citrus Flowering, In: Hort. Reviews, J. Janick (ed.) 12, 349408. Timber press. Portland. 
Davies, F.S. and Albrigo L.G. (1994) Citrus. GAB International Press. Walling ford, UK. 254 p.

El-Otmani, M., Ait-Oubahou, A., Tadili, A., El-Hila M. and Lovatt, C.J. (1998a) Effect of fall/ winter application of foliar urea on flowering and yield of Nour clementine mandarin. Hortscience. 33, 549 (Abstr).

El-Otmani, M., Tadili A. and Ait-Oubahou A. (1998b) Amelioration de La misea-fleur chezle Clementineire Nour par 1 utilisation de 1 urea enpulverisation foliar. de La Research en Agrumiculture. Institut Agronomique et Veterinaire Hassan II. Agadir. p. 71-79.

El-Otmani, M., Taibi, F.Z., Lmoufid, B. and Ait-Oubahou, A. (2000a) Utilisation de La fertilization forliaire a urea pour amelioration des compsantes du rendement agrumiculture. Premier Congres National des Sciences du sol. Meknes, Morocco 1819 March. Recueil des Resumes (Abstr).

El-Otmani, M., El-Hila, M., Lmoufid, B., Ait-Oubahou, A. and Lovatt, C.J. (2000b) Amelioration des composants du rendement chez Le clementinier par La fertilization foliar a urea. Premier Congres National des Sciences du sol. Mchnes, Morocco.18-19.

El-Otmani, M. (2002) Effect of foliar urea as an $\mathrm{N}$ source in sustainable citrus production systems. Acta Hortuculterae, 594, 82-83

Erickson, L.C. and Brannaman (1960) Abscission of reproductive structures and leaves of orange trees. Proc. Amer. Soc. Hort. Sci., 75, 222-229.

Krogmeier, M.J., Mcarty, G.W. and Bremner, J.M. (1989) Phytotoxicity of foliar application urea.. Proc. Natl. Acad. Sci., 86, 8189-8191.

Matros, A., Amme, S., Kettig, B., and Buck-Sorlin, G.H. ( 2006 ) Growth of elevated $\mathrm{CO}_{2}$ concentrations leads to modified profiles of secondary metabolites in tobacco CV. Plan. Cell Environ. 29, 126-137.

Moss, G.I. (1971) Effect of fruit on flowering in relation to bionnial bearing in Sweet orange (Citrus sinensis) J. Hort. Sci., 46, 177-184.

Mostafa, S.S. (1985) Comparative study on the flowering and fruiting Balady and selected-malawi mandarins. Ph.D. Cairo Univ.

Norbaek, R., Aaboer, D.B. , Bleeg, I.S., Christensen, B.T. , Kondo, T., Brandt, K. and Flavon C.(2003) Phenolic acid and nitrogen contents in leaves of barly subject to organic fertilization treatments. J. Agric. Food Chem. 51, 809-813.

Lord, E.M. and Eckard, K.J. (1987) Shoot development in Citrus sinensis L. (Washington Navel orange). Bot. Gaz., 148, 17-22.

Lovatt, C.J, Zheng, Y. and Hake, K.D. (1988a) Demonstration of a change in Nitrogen metabolism influencing flower initiation in citrus. Isr. J. Bot., 37, 181-188.

Lovatt, C.J., Zheng, Y. and Hake, K.D. (1988b) A new look at the kraus-kraybill hypothesis and flowering of citrus. Proc. $6^{\text {th }}$ Int. Citrus Congr., 1, 475-483.

Egypt. J. Hort. Vol. 43, No.2 (2016) 
Lovatt, C.J., Sagee, O. and Ali, A.G. (1992) Ammonia and/or its metabolites influence flowering, fruit set and yield of Navel orange. Proc. Int. Soc. Citricult., 1, 412-416

Lovatt, C.J. (1999) Timing Citrus and Avocado foliar nutrient applications to increase fruit set and size. HortTechnology. 9 (4) 607-612.

Rabe, E. (1994) Yield benefits associated with pre-bloom low biuret urea sprays on Citrus. Spp. J. Hort. Sci., 69, 495-500.

Radi, M., Mahrouz, M., Jaouad, A. and Amiot, M.J. (2003) Influence of mineral fertilization (NPK) on the quality of apricot fruit. Agronomi., 23, 737-745 .

Sagee, O. and Lovatt, C.J. (1991) Putrescine concentration parallels a ammonia and arginine metabolism in developing flower of Washington Navel orange . J. Amer. Soc. Hort. Sci., 116, 280-285.

Steel, R.G. and Torrie, G.H. (1984) Principles and Procedures of Statistics. "A Biometrical Approach", $4^{\text {th }}$ ed., Mc Graw-Hill, USA.

Witzell, J. and Shevtsova, A. (2004) Nitrogen induced changes in phenolics of Vaccinium myrtillus-implications for interaction with a parasitic fungus. J. Chem. Ecol., 34, 1007-1017.

(Received 15/8/2016;

accepted 17/11/2016) 


\title{
تاثير الرش باليوريا على الازهار والعقد والمحصول وجودة ثمار أشجار

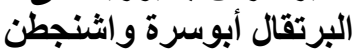

\author{
فيصل سامى السيا ومحمد محمد ابو العينين ومنى محمد هلال \\ معهز بحوث البساتين ـ مركز البحوث البوث الزر اعينة ـ القاهرة ـ مصر.

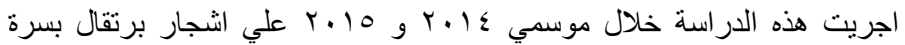

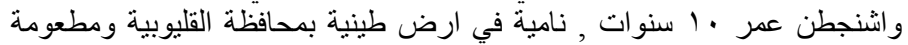

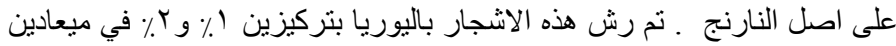

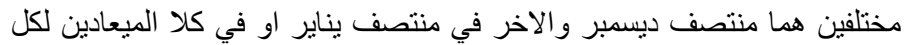

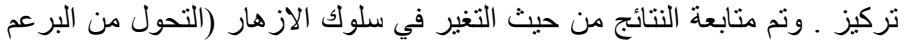

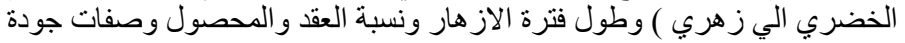

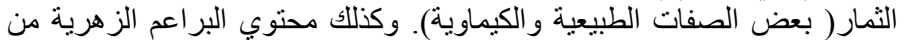

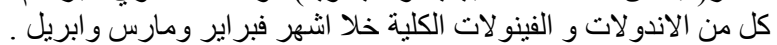 \\ و اثبتت الدراسات المرفولوجية والتشريحية ان الرش باليوريا وخاصة معاملة

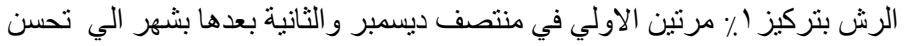

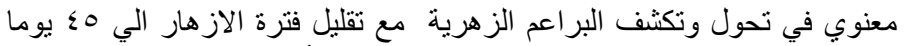

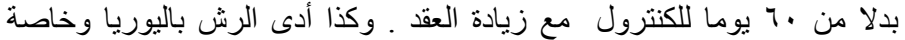

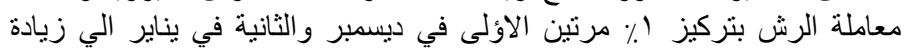

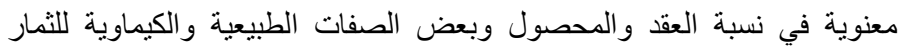

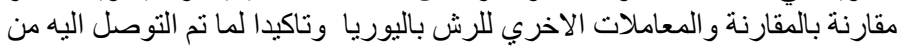

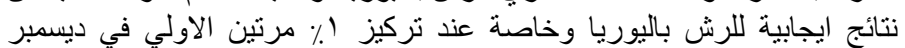

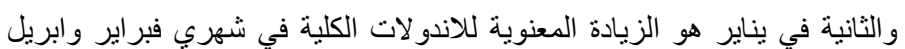

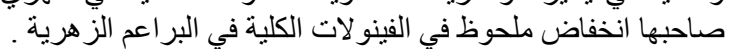 \\ ومما سبق يمكن التوصية برش اشجار البرتقال ابو سرة سنويا باليوريا بتركيز

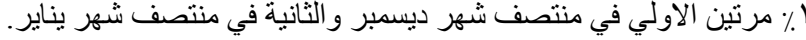

